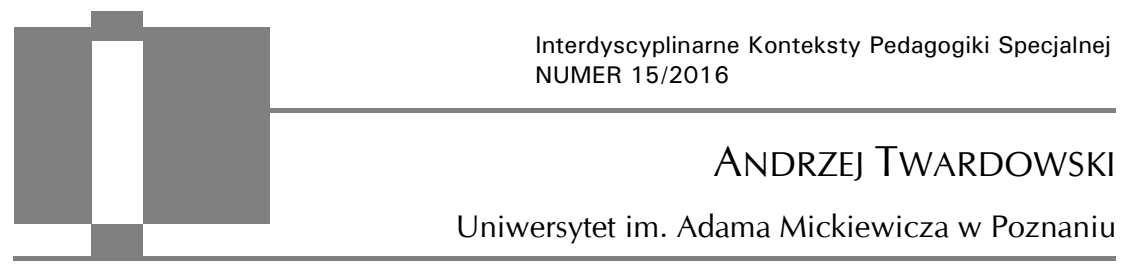

\title{
Rola rówieśniczego tutoringu w rozwijaniu umiejętności komunikacyjnych dzieci przedszkolnych z niepełnosprawnościami
}

\begin{abstract}
Andrzej Twardowski, Rola rówieśniczego tutoringu w rozwijaniu umiejętności komunikacyjnych dzieci przedszkolnych z niepetnosprawnościami [The role of peer tutoring in developing communication skills of preschool children with disabilities]. Interdyscyplinarne Konteksty Pedagogiki Specjalnej, nr 15, Poznań 2016. Pp. 43-64. Adam Mickiewicz University Press. ISSN 2300-391X

This article provides an overview of two approaches to peer-mediated intervention that have been effective in improving the social and communicative interactions among preschool children with developmental disabilities and their classmates without disabilities. These peer-mediated interventions involve teaching facilitative initiation and responsive interaction strategies to peers and teaching sociodramatic scripts. The studies presented in this paper prove that thanks to relationships with properly trained peers disabled children more often get involved in team games, more often establish interactions with their peers, are more eager to talk to them and less often exhibit socially unacceptable behaviors.
\end{abstract}

KEY WORDS: peer tutoring, communication skills, preschool children, developmental disabilities 


\section{Wstęp}

Do końca lat 70. ubiegłego wieku dziecko było traktowane jak „puste naczynie”, które dzięki nauczającym oddziaływaniom dorosłych stopniowo „napełnia się" wiedzą i umiejętnościami. Zakładano, że decydujący wpływ na rozwój dziecka mają osoby dorosłe. Nie brano pod uwagę, że dzieci mogą uczyć się nawzajem. Dopiero opublikowana w roku 1990 praca pod redakcją Hugh Foot, Michelle Morgan i Rosalyn Shute podważyła tezę, że relacje z dorosłymi są głównym motorem rozwoju psychicznego dziecka ${ }^{1}$. Wykazano w niej, że od pierwszych tygodni życia dziecko wchodzi w sieć społecznych związków z różnymi osobami i że w jego rozwoju bardzo ważną rolę odgrywają relacje z rówieśnikami. Udokumentowano, że $w$ tych relacjach dzieci mogą występować $w$ rolach nauczycieli i pomocników, pod warunkiem, że stworzy się im odpowiednie warunki i uczyni współodpowiedzialnymi za przebieg procesu uczenia ${ }^{2}$.

Badania prowadzone w ostatnim trzydziestoleciu wykazały, że kontakty z rówieśnikami pozytywnie wpływają na rozwój ruchowy, poznawczy, społeczny i emocjonalny dziecka. W relacjach z rówieśnikami dziecko uczy się nawiązywać kontakty społeczne, współpracować, pomagać i dzielić się. Nabywa takie kompetencje, jak: zgłaszanie inicjatyw, obrona własnych interesów, negocjowanie, osiąganie zamierzonych celów, podporządkowywanie się woli innych i odgrywanie roli przywódcy. Interakcje z rówieśnikami wspierają rozwój poznawczy. Stwierdzono, że sama obecność kolegów wpływa mobilizująco na aktywność umysłową dziecka. Np. dzieci $\mathrm{w}$ wieku przedszkolnym $\mathrm{w}$ obecności rówieśników rozwiązywały zadania szybciej i lepiej niż wówczas, gdy rozwiązywały je

${ }^{1}$ H.C. Foot, M.J. Morgan, R.H. Shute, Children helping children, John Wiley \& Sons, New York 1990, s. 3-17.

2 A. Twardowski, Wptyw nauczających relacji z petnosprawnymi rówieśnikami na rozwój dzieci z niepetnosprawnościami, [w:] Pedagogika specjalna - koncepcje i rzeczywistość. Socjopedagogiczne aspekty rehabilitacji osób niepetnosprawnych, red. T. Żółtkowska, M. Wlazło, ZAPOL, Szczecin 2008, s. 145-146. 
w samotności ${ }^{3}$. Kontakty z rówieśnikami pobudzają również rozwój emocjonalny dziecka. Sprzyjają kształtowaniu się zdolności do empatii i samokontroli emocjonalnej, rozpoznawania emocji partnerów oraz umiejętności wyrażania emocji w sposób społecznie akceptowany.

Celem tego opracowania jest udokumentowanie tezy, że pełnosprawne dzieci $\mathrm{w}$ wieku przedszkolnym mogą $\mathrm{z}$ powodzeniem odgrywać role tutorów w relacjach $\mathrm{z}$ niepełnosprawnymi rówieśnikami. Rozpocznę od omówienia typów rówieśniczego tutoringu i ukazania ich teoretycznych podstaw. Następnie przeanalizuję dwie główne formy rówieśniczego tutoringu stosowanego w terapii dzieci z niepełnosprawnościami w wieku przedszkolnym - uczenia przez pełnosprawnych rówieśników oraz uczenia się z pełnosprawnymi rówieśnikami w trakcie zabaw tematycznych.

\section{Typy rówieśniczego tutoringu}

W literaturze przedmiotu wyróżniono dwa typy rówieśniczych interakcji o charakterze nauczającym: „uczenie przez rówieśnika” (ang. peer tutoring) oraz uczenie się z rówieśnikiem (ang. peer collaboration $)^{4}$.

„Uczenie przez rówieśnika” opisuje sytuację, w której jedno dziecko (tutor) pomaga drugiemu (uczniowi) opanować określone wiadomości i umiejętności poprzez przekazywanie instrukcji lub bezpośrednie kierowanie czynnościami partnera. Zazwyczaj tutorzy

${ }^{3}$ C.R. Cooper, Development of collaborative problem-solving among preschool children, "Developmental Psychology" 1980, nr 5, s. 433-440.

${ }^{4}$ William Damon i Erin Phelps wyróżniają jeszcze "uczenie się zespołowe” (ang. cooperative learning). Termin ten opisuje sytuację, kiedy nauczyciel dzieli uczniów danej klasy na kilkuosobowe zespoły i członkowie każdego z nich rozwiązują określony problem lub zadanie współpracując ze sobą, ponieważ tylko dzięki współpracy mogą osiągnąć sukces. (W. Damond, E. Phelps, Strategies uses of peer learning in children's education, [w:] Peer relationships in child development, red. T.J. Berndt, G.W. Ladd, John Willey \& Sons, New York 1989, s. 135-157). 
są w tym samym wieku metrykalnym co uczniowie, a tylko czasami są nieco starsi. Natomiast pomimo tego samego lub zbliżonego wieku, między dziećmi występuje różnica w poziomie kompetencji. Tutor posiada wyższy poziom wiedzy i umiejętności od ucznia, jest ekspertem, a uczeń nowicjuszem. Relacja między nimi ma charakter asymetryczny. Ekspert dostarcza wskazówek, instrukcji i porad oraz kieruje wysiłkami nowicjusza mającymi na celu rozwiązanie określonego zadania 5 .

Uczenie przez rówieśnika znajduje uzasadnienie w koncepcji Lwa Wygotskiego ${ }^{6}$. Według tej koncepcji rozwój psychiczny dziecka dokonuje się $\mathrm{w}$ relacjach $\mathrm{z}$ osobami, które wiedzą więcej o kulturowo akceptowanych sposobach działania i narzędziach, wśród których najważniejszy jest język. Najpierw wiedza i umiejętności są doświadczane w interakcji społecznej, a dopiero później zostają zinternalizowane i ulegają dekontekstualizacji. Aby ukazać społeczno-interakcyjną naturę rozwoju, Lew Wygotski zaproponował koncepcje „strefy najbliższego rozwoju”7. Według niego kluczowe znaczenie dla rozwoju psychicznego ma rozwiązywania problemów pod kierunkiem i we współpracy z dorosłymi i kompetentniejszymi rówieśnikami. Koncepcja strefy najbliższego rozwoju opiera się na założeniu, że różnica w poziomach kompetencji musi iść $w$ parze $z$ lepszym rozumieniem przez tutora potrzeb nowicjusza, ponieważ informacje podawane w sposób znacznie przekraczający możliwości poznawcze nowicjusza byłyby nieprzydatne. Teoria Lwa Wygotskiego wymaga więc, aby związek między tutorem i nowicjuszem był relacją intersubiektywną, w której zawarta jest pewna doza wspólnego zrozumienia. Dla Wygotskiego idealni partnerzy to tacy, którzy nie są sobie równi, przy czym nierówność

${ }^{5}$ A. Twardowski, Możliwości wykorzystania rówieśniczego tutoringu w edukacji dzieci z niepetnosprawnościq intelektualna, „Interdyscyplinarne Konteksty Pedagogiki Specjalnej" 2014, nr 5, s. 21-22.

${ }^{6}$ L.S. Wygotski, Wybrane prace psychologiczne, PWN, Warszawa 1971.

${ }^{7}$ Strefa najbliższego rozwoju to różnica między poziomem kompetencji, jaki dziecko ujawnia wykonując jakieś zadanie przy pomocy kogoś „wiedzącego więcej” a poziomem, jaki ujawnia wykonując zadanie samodzielnie. 
dotyczy rozumienia, a nie władzy. „Z tego powodu zarówno dorośli, jak i rówieśnicy mogą przyczynić się do rozwoju poznawczego dziecka w toku interakcji. Aby jednak rozwój ten mógł zachodzić podczas interakcji rówieśniczej, konieczny jest wyższy stopień przygotowania któregoś z partnerów"8.

Termin „uczenie się z rówieśnikiem” opisuje sytuację, w której dzieci o podobnym poziomie zdolności dzielą się informacjami, aby rozwiązać określone zadanie. Wiedza posiadana przez dzieci jest niepełna i dlatego żadne $\mathrm{z}$ nich nie potrafi rozwiązać zadania samodzielnie. Natomiast mogą je rozwiązać we współpracy, wymieniając się posiadanymi informacjami i pomagając sobie w zdobywaniu nowych. Jest to uczenie się poprzez wspólne odkrywanie. Dokonuje się w ramach symetrycznej relacji, w atmosferze wzajemnej sympatii i przy równym zaangażowaniu obojga partnerów ${ }^{9}$.

Uczenie się $\mathrm{z}$ rówieśnikiem znajduje uzasadnienie $\mathrm{w}$ teorii Jeana Piageta, który podkreślał, że interakcja dziecka z dorosłym jest asymetryczna, ponieważ dorosły ma większą wiedzę i władzę, a to narusza warunek wzajemności niezbędny do osiągnięcia zrównoważenia struktur poznawczych ${ }^{10}$. Ze względu na fakt, że punkt widzenia dorosłego dominuje, dziecko porzuca swoje pomysły, często jeszcze słabo skrystalizowane i niemogące konkurować z pomysłami dorosłego. Ponieważ dziecko zgadza się z pomysłami dorosłego, nie uczy się ich samodzielnego weryfikowania. Zgadzanie się z dorosłym nie prowadzi do poznawczej restrukturyzacji, a tym samym nie stymuluje rozwoju umysłowego dziecka. Inaczej jest w relacjach z rówieśnikami, ponieważ charakteryzują się równowagą zdolności poznawczych i władzy. W sytuacji, kiedy partner ma odmienne zdanie, dziecko dąży do wyjaśnienia swojego punku widzenia poprzez skonfrontowanie go z punktem widzenia partne-

${ }^{8}$ J. Tudge, B. Rogoff, Wptyw rówieśników na rozwój poznawczy - podejście Piageta i Wygotskiego, [w:] Dziecko wśród rówieśników i dorostych, red. A. Brzezińska, G. Lutomski, B. Smykowski, Zysk i S-ka, Poznań 1995, s. 191.

${ }_{9}$ A. Twardowski, Możliwości wykorzystania rówieśniczego tutoringu..., s. 22.

${ }^{10}$ J. Piaget, Mowa i myślenie u dziecka, Książnica - Atlas, Warszawa - Lwów 1929. 
ra. Zatem kontakty z rówieśnikami wywołują konflikty poznawcze i zmuszają dziecko do ich rozwiązywania. Tym samym skłaniają partnerów do intelektualnej współpracy i przyczyniają się do przezwyciężenia przez nich egocentryzmu poznawczego. Mówiąc inaczej: interakcja społeczna staje się źródłem postępu w rozwoju poznawczym dzięki temu, że prowadzi do konfliktu społeczno-poznawczego. „Oczywiście konflikt społeczno-poznawczy sam z siebie nie tworzy nowych form operacji umysłowych, natomiast doprowadza do utraty równowagi, co z kolei wyzwala aktywność poznawczą. Konflikt społeczno-poznawczy działa jak katalizator w reakcji chemicznej: choć nie jest obecny w końcowym produkcie, to jest niezbędny, aby reakcja mogła nastąpić" 11 .

\section{Tutoring w formie uczenia przez pełnosprawnych rówieśników}

Pierwszą udaną próbę przygotowania pełnosprawnych rówieśników do roli tutorów przeprowadził Phillip Strain ze współpracownikami w latach 70 . ubiegłego wieku12. Badacze za pomocą procedury modelowania nauczyli czteroletnie dzieci o ilorazie inteligencji powyżej 130 punktów i bardzo wysokim poziomie rozwoju społecznego różnych sposobów zapraszania kolegów do wspólnej zabawy. Przeszkolone dzieci miały okazję wykorzystać nabyte umiejętności $\mathrm{w}$ trakcie zabaw $\mathrm{z}$ trojgiem rówieśników w wieku od 3,7 do 4,3 lat ${ }^{13}$, niepełnosprawnych intelektualnie w stopniu umiarkowanym. Niepełnosprawne dzieci ujawniały znaczne opóźnienie rozwoju mowy oraz nie reagowały na prośby opiekunów. Terapeutyczne sesje $\mathrm{z}$ udziałem pełnosprawnych tutorów odbywały się

11 A.N. Perret-Clermont, Social interaction and cognitive development in children, Academic Press, London 1980, s. 178.

12 P.S. Strain, Effects of peer social initiations on withdrawn preschool children: Some training and generalization, "Journal of Abnormal Child Psychology" 1977, nr 5, s. $445-455$.

13 Pierwsza cyfra oznacza rok życia, a druga - miesiąc. 
codziennie, w oddzielnym pokoju, przez 15 minut. Już po kilkunastu dniach niepełnosprawne dzieci zaczęły włączać się we wspólne zabawy oraz podejmować rozmowy. Później ta sama procedura była $\mathrm{z}$ powodzeniem stosowana $\mathrm{w}$ odniesieniu do kolejnych dzieci niepełnosprawnych intelektualnie z opóźnionym rozwojem mowy, a także w stosunku do dzieci autystycznych, które nie nawiązywały kontaktów z rówieśnikami i nie reagowały na polecenia opiekunów. Po serii kilkunastu sesji terapeutycznych z pełnosprawnymi tutorami wszystkie niepełnosprawne dzieci częściej włączały się w kontakty interpersonalne i częściej je inicjowały. Ponadto wyraźnie spadła u nich liczba zachowań aspołecznych, a wzrosła liczba zachowań prospołecznych ${ }^{14}$. W kolejnych badaniach prowadzonych przez zespół Phillipa Straina pełnosprawne dzieci uczyły się, jak zachęcać niepełnosprawnych rówieśników do porozumiewania się poprzez zadawanie pytań, nakłanianie do udzielenia odpowiedzi oraz podawanie gotowej wypowiedzi i proszenie o jej powtórzenie ${ }^{15}$.

Przygotowanie pełnosprawnego dziecka do roli tutora odbywa się w trzech etapach. Najpierw terapeuta wyjaśnia pełnosprawne$\mathrm{mu}$ dziecku dlaczego powinno nawiązywać interakcje z niepełnosprawnymi kolegami i bawić się z nimi. Następnie zaznajamia tutora $z$ istotą pierwszej strategii. $W$ drugim etapie terapeuta uczy dziecko, w jaki sposób powinno posługiwać się strategią w kontaktach $\mathrm{z}$ niepełnosprawnymi rówieśnikami. W tym celu demonstruje różne, potencjalne reakcje niepełnosprawnych partnerów i uczy dziecko, jak ma na nie reagować. $W$ trzecim etapie sprawdzany jest stopień opanowania strategii przez tutora i wprowadzane są niezbędne korekty. Odbywa się to w naturalnych warunkach, tzn. w grupie przedszkolnej, zazwyczaj podczas zabaw dowolnych.

14 P.S. Strain, R.E. Shores, M.A. Timm, Effects of peer social initiation on the behavior of withdrawn preschool children, "Journal of Applied Behavior Analysis" 1977, nr 10, s. 289-298.

15 P.S. Strain, M.M. Kerr, E.U. Regland, Effects of peer-mediated social initiation and prompting/reinforcement procedures on the social behavior of autistic children, "Journal of Autism and Developmental Disorders" 1979, nr 9, s. 41-54. 
Terapeuta uważnie obserwuje poczynania tutora i w razie potrzeby stosuje trzy typy podpowiedzi. Pierwszy to wyrażane wprost werbalne instrukcje - na przykład: „Zaproponuj Jankowi grę w bierki”, „Spróbuj mówić o dinozaurze, którego Jacek trzyma”. Drugi typ to podpowiedzi ogólniejsze: „Teraz twoja kolej, aby coś powiedzieć", „Spróbuj jeszcze raz". Podpowiedzi trzeciego typu mają charakter niewerbalny. Terapeuta posługuje się obrazkami (np. rysunkiem przedstawiającym parę rozmawiających dzieci) lub gestami (np. pokazuje rękami, aby tutor zbliżył się do partnera). Kiedy tutor opanuje pierwszą strategię, terapeuta przystępuje do uczenia drugiej, a później kolejnych.

Bardzo ważne jest pytanie: jakie strategie stosowane przez tutora najbardziej sprzyjają rozwojowi umiejętności komunikacyjnych u niepełnosprawnych rówieśników? Badacze starali się zidentyfikować takie strategie, analizując wyniki badań nad rozwojem mowy we wczesnych stadiach ontogenezy oraz badań nad nawiązywaniem interakcji społecznych przez małe dzieci. Howard Goldstein i Susan Wickstrom wyodrębnili sześć strategii, które powinny ułatwiać niepełnosprawnym partnerom zapoczątkowanie komunikacyjnej interakcji i podtrzymanie jej przez pewien czas ${ }^{16}$. Były to: 1) nawiązywanie kontaktu wzrokowego, 2) tworzenie wspólnego pola uwagi, 3) inicjowanie wspólnej zabawy, 4) zachęcanie partnera do wyrażania próśb, 5) mówienie o czynnościach wykonywanych przez siebie lub partnera oraz 6) reagowanie na wypowiedzi partnera - ich powtarzanie, rozszerzanie lub proszenie o dodatkowe informacje. Nauczyciel ułatwiał tutorom prowadzenie oddziaływań, pokazując im w razie konieczności obrazki ilustrujące poszczególne strategie. Po 20 sesjach terapeutycznych poziom umiejętności nawiązywania kontaktów społecznych przez dzieci $\mathrm{z}$ autyzmem wzrósł i utrzymywał się po zakończeniu oddziaływań.

Ważna jest nie tylko jakość strategii opanowanych przez tutorów, ale również ich liczba. Można bowiem zastanawiać się, czy

${ }^{16} \mathrm{H}$. Goldstein, S. Wickstrom, Peer intervention effects on communicative intervention among handicapped and nonhandicapped preschoolers, "Journal of Applied Behavior Analysis" 1986, nr 19, s. 209-214. 
posługiwanie się przez tutorów wieloma strategiami nie będzie wymagało intensywniejszego nadzoru nauczycieli nad nauczającymi relacjami między dziećmi. I wtedy rodzi się pytanie: w jakim stopniu pozytywne zmiany w umiejętnościach komunikacyjnych niepełnosprawnych dzieci spowodowane są oddziaływaniami pełnosprawnych tutorów, a w jakim - podpowiedziami kierowanymi do tutorów przez nauczycieli? Można się też zastanawiać, czy tutorzy potrafią z powodzeniem stosować nabyte strategie, gdy podpowiedzi i wzmocnienia ze strony nauczycieli zostaną wycofane. Dlatego w kolejnych badanich Howard Goldstein i Donald Ferrell postanowili ograniczyć liczbę strategii opanowywanych przez tutorów do czterech ${ }^{17}$. Były to: 1) inicjowanie kontaktu wzrokowego lub pola wspólnej uwagi, 2) inicjowanie wspólnej zabawy, 3) mówienie o czynnościach wykonywanych w trakcie zabawy oraz 4) odpowiadanie na komunikacyjne inicjatywy partnera. Przeszkolono sześcioro pełnosprawnych dzieci w wieku przedszkolnym. Okazało się, że wszystkie opanowały ułatwiające strategie i potrafiły się nimi posługiwać $\mathrm{w}$ relacjach $\mathrm{z}$ trzema niepełnosprawnymi intelektualnie rówieśnikami ujawniającymi takie zaburzenia zachowania jak: nieumiejętność nawiązania kontaktów społecznych, brak reakcji na próby nawiązania kontaktu, nieumiejętność uczestniczenia w zabawach oraz brak reakcji na prośby i polecenia nauczycielek. Po przeprowadzeniu 20 sesji terapeutycznych u dzieci niepełnosprawnych intelektualnie stwierdzono znaczny wzrost liczby społecznokomunikacyjnych interakcji z pełnosprawnymi rówieśnikami oraz wyraźny spadek liczby wymienionych wyżej zachowań nieprawidłowych. Stwierdzono, że tutorzy starali się używać tych strategii, które $\mathrm{w}$ relacji z danym partnerem były najskuteczniejsze. Np. gdy partner był mało responsywny, wówczas usilnie starali się nawiązać z nim kontakt wzrokowy.

Wybór strategii, których pełnosprawni tutorzy powinni używać, nie jest łatwym zadaniem, ponieważ na przebieg ich interakcji

${ }^{17}$ H. Goldstein, D.R. Ferrell, Augmenting communicative interaction between handicapped and nonhandicapped preschool children, "Journal of Speech and Hearing Disorders" 1987, nr 52, s. 200-219. 
z niepełnosprawnymi partnerami wpływa wiele czynników, m.in.: rodzaj aktywności, używane materiały, zakres wsparcia udzielanego przez terapeutę, poziom rozwoju partnera, stopień zażyłości z partnerem, wielkość grupy. Donald Ferrell przeprowadził badania, w których wymienione zmienne były kontrolowane. Celem badań było ustalenie, jakich strategii należałoby uczyć pełnosprawnych tutorów ${ }^{18}$. Autor analizował przebieg zabaw 10 pełnosprawnych dzieci uczęszczających do integracyjnego przedszkola. Partnerami zabaw byli rówieśnicy o różnym poziomie rozwoju: pełnosprawni, niepełnosprawni w stopniu umiarkowanym i niepełnosprawni w stopniu znacznym. Szczegółowe analizy przebiegu zabaw pozwoliły ustalić, że trzy strategie stosowane przez pełnoprawne dzieci najczęściej wywoływały odpowiedzi partnerów i zapoczątkowywały komunikacyjne wymiany. Pierwsza, o charakterze niewerbalnym, to podzielanie uwagi z partnerem i kierowanie jej na określony przedmiot lub działanie. Istotą drugiej strategii było komentowanie działań partnera lub proszenie o informacje na ich temat. Trzecia strategia polegała na formułowaniu wypowiedzi akceptujących treść werbalnych lub niewerbalnych komunikatów partnera. Ponadto stwierdzono, że dla sprawnego przebiegu komunikacyjnej interakcji najważniejsza była równowaga między ilościami wypowiedzi sformułowanych przez każdego z partnerów. Natomiast długość ich wypowiedzi nie była istotna.

Howard Goldstein i współpracownicy zainspirowani przedstawionymi wyżej badaniami, postanowili uprościć procedurę szkolenia tutorów ${ }^{19}$. Uczyli pełnosprawne dzieci w wieku przedszkolnym asystowania rówieśnikowi z autyzmem, komentowania jego za-

18 D.R. Ferrell, Communicative interaction between handicapped and nonhandicapped preschool children: Identifying facilitative strategies. Nieopublikowana praca doktorska, University of Pittsburgh, Pittsburgh 1990. Cyt. za: H. Goldstein, N. Schneider, K. Thiemann, Peer-mediated social communication intervention. When clinical expertise inform treatment development and evaluation, "Topics in Language Disorders" 2007, nr 2, s. 187.

${ }^{19}$ H. Goldstein, K. English, K. Shafer, L. Kaczmarek. Interaction among preschoolers with and without disabilities. Effects of across-the-day peer intervention, "Journal of Speech, Language and Hearing Research" 1997, nr 40, s. 33-48. 
chowań oraz akceptowania zachowań pożądanych. M.in. uczyli tutorów, aby: stawali obok niepełnosprawnego kolegi, przyglądali się wykonywanym przez niego czynnościom, wypowiadali imię kolegi, kładli dłoń na jego ramieniu, wypowiadali się na temat jego czynności, czekali na odpowiedź, a następnie formułowali kolejną wypowiedź nawiązującą do odpowiedzi kolegi. Po przeprowadzeniu szkolenia podjęto oddziaływania terapeutyczne. Stworzono pięć triad, z których każda składała się z jednego dziecka autystycznego oraz dwóch pełnosprawnych tutorów. Po zakończeniu terapii stwierdzono istotny wzrost społeczno-komunikacyjnych umiejętności u czworga dzieci z autyzmem. Największy wzrost odnotowano u dwojga dzieci, które nie posługiwały się mową i których rozwój poznawczy był najbardziej opóźniony.

Uproszczoną procedurę szkolenia tutorów zastosowano w kolejnych badaniach przeprowadzonych przez grupę Howarda Goldsteina $^{20}$. Ośmioro dzieci w wieku przedszkolnym uczono strategii, którą nazwano „Bądź - Baw się - Rozmawiaj”. Chodziło o to, aby tutorzy pozostawali w pobliżu swoich niepełnosprawnych kolegów, podejmowali z nimi zabawy i w ich trakcie toczyli rozmowy. Po zakończeniu szkolenia tutorzy zostali połączeni w pary z niepełnosprawnymi intelektualnie kolegami. Zachęcano tutorów, aby posługiwali się opanowaną strategią podczas zabaw dowolnych, przerw na śniadanie oraz zajęć w małych grupach. W trakcie oddziaływań terapeutycznych następował stały wzrost ilości i jakości społeczno-komunikacyjnych interakcji w poszczególnych parach. Podobny, a nawet większy wzrost zaobserwowano po rotacji par, czyli po przydzieleniu tutotorom nowych partnerów, którymi wcześniej zajmował się ktoś inny.

O skuteczności tutoringu w formie uczenia przez pełnosprawnych rówieśników świadczy nie tylko wzrost częstości i jakości interakcji między tutorem a uczniem. Bardzo istotne jest również, czy

${ }^{20}$ K. English, K. Shafer, H. Goldstein, L Kaczmarek, Teaching buddy skills to preschoolers, [w:] Mental retardation and intellectual disabilities. Teaching students using innovative and research-based strategies, red. L. Wehmeyer, M. Agran, American Association on Mental Retardation, Annapolis Junction 2005, s. 177-195. 
szkolenie tutorów skutkuje wzrostem społeczno-komunikacyjnych umiejętności $u$ innych dzieci w grupie przedszkolnej. Można przypuszczać, że niepoddani szkoleniu rówieśnicy przejmują te umiejętności dzięki procesowi modelowania. Problem ten postanowiła rozstrzygnąć Diane Sainato ze współpracownikami21. Autorzy nauczyli troje pełnosprawnych dzieci w wieku przedszkolnym posługiwania się czterema strategiami: pozyskiwania uwagi partnera, sugerowania pomysłu zabawy, dzielenia się zabawkami i materiałami oraz udzielania partnerowi odpowiedzi. Sesje terapeutyczne były prowadzone w trzech triadach, z których każda składała się z: tutora, nieprzeszkolonego pełnosprawnego rówieśnika oraz dziecka z autyzmem. Przed każdą sesją tutorzy przeglądali książeczkę z obrazkami ilustrującymi poszczególne strategie i planowali, jak je zastosują. Po sesji oceniali własną skuteczność w posługiwaniu się każdą strategią, zakreślając ikonę uśmiechniętej lub smutnej twarzy. Trafne oceny były nagradzane przez terapeutę. Procedura samooceniania spowodowała znaczny wzrost częstości stosowania nauczających strategii przez tutorów i w konsekwencji znaczną poprawę $\mathrm{w}$ funkcjonowaniu dzieci $\mathrm{z}$ autyzmem. Ponadto opanowane strategie pozostały $\mathrm{w}$ repertuarze zachować tutorów i były przez nich wykorzystywane $\mathrm{w}$ relacjach $\mathrm{z}$ innymi dziećmi niepełnosprawnymi. Niestety, nie zaobserwowano istotnych, pozytywnych zmian w zachowaniach pełnosprawnych rówieśników niepoddanych szkoleniu. Niewątpliwie problem ten wymaga dalszych badań na liczniejszej grupie.

\section{Tutoring w formie uczenia się z pełnosprawnymi rówieśnikami}

W przypadku dzieci w wieku przedszkolnym największe możliwości organizowania tutoringu $\mathrm{w}$ formie uczenia się $\mathrm{z}$ pełno-

${ }^{21}$ D. Sainato, H. Goldstein, P. Strain, Effects of self-evaluation on preschool children's use of social interaction strategies with their classmates with autism, "Journal of Applied Behavior Analysis" 1992, nr 25, s. 920-927. 
sprawnymi rówieśnikami stwarzają zabawy tematyczne. Należy jednak wziąć pod uwagę trudności, jakie mogą pojawić się, gdy uczestnikami zabaw są zarówno dzieci sprawne, jak i niepełnosprawne. Po pierwsze istnieje ryzyko, że dzieciom niepełnosprawnym przypadną $\mathrm{w}$ udziale tylko niektóre role - np. w zabawie w lekarza rola pacjenta. Po drugie przebieg zabawy może szybko ulec wypaczeniu. Np. podczas zabawy w restaurację dzieci mogą porzucić swoje role i zacząć manipulować posiadanymi akcesoriami. Po trzecie zauważono, że tematyka zabaw z udziałem dzieci sprawnych i niepełnosprawnych jest uboga, a ich przebieg schematyczny ${ }^{22}$. Dlatego aby uniknąć tego typu problemów, konieczne jest: staranne zaznajomienie dzieci ze scenariuszami zabaw, nauczenie ich zabawowych ról, dopilnowanie prawidłowego przydziału ról oraz monitorowanie przebiegu zabaw.

Pierwsze dwa badania nad skutecznością uczenia się z pełnosprawnymi rówieśnikami z wykorzystaniem zabaw tematycznych przeprowadził zespół Howarda Goldsteina ${ }^{23}$. W pierwszym badaniu uczestniczyły dwie triady dzieci uczęszczających do integracyjnego przedszkola. W każdej triadzie było dwoje dzieci pełnosprawnych i jedno, u którego zdiagnozowano zaburzenia zachowania i opóźniony rozwój mowy. Badacze posłużyli się scenariuszem zabawy w stoisko $z$ hamburgerami. W scenariuszu zawarto zarówno werbalne, jak i niewerbalne komunikaty przypisane w podobnej liczbie do ról kucharza, sprzedawcy i klienta. Najpierw nauczycielka zaznajamiała dzieci ze scenariuszem zabawy i instruowała, jak mają odgrywać poszczególne role. Następnie zachęcała dzieci do samodzielnego kontynuowania zabawy i nadzorowała prawidłowość jej przebiegu. Samo nauczenie się scenariusza zabawy nie poprawiło jakości interakcji między dziećmi. Natomiast później, kiedy

${ }^{22}$ H. Goldstein, N. Schneider, K. Thiemann, Peer-mediated social communication intervention. When clinical expertise inform treatment development and evaluation, “Topics in Language Disorders" 2007, nr 2, s. 190.

${ }^{23}$ H. Goldstein, S. Wickstrom, M. Hoyson, B. Jemieson, S. Odom, Effects of sociodramatic script training on social and communication interaction, "Education and Treatment of Children" 1988, nr 11, s. 97-117. 
dzieci bawiły się samodzielnie, a nauczycielka podpowiadała im, jak grać role i kiedy powinni się nimi wymienić, zaobserwowano znaczną poprawę jakości społecznych i komunikacyjnych interakcji między dziećmi sprawnymi i niepełnosprawnymi. Co więcej, dzieci okazały się twórcze, ponieważ rozbudowały repertuar wypowiedzi o takie, których scenariusz zabawy nie zawierał.

W drugim badaniu uczestniczyły dwie triady składające się wyłącznie z dzieci niepełnosprawnych: z zespołem Downa, z dyslalią oraz z niedosłuchem ${ }^{24}$. Obie triady uczyły się scenariusza zabawy w salon fryzjerski. Podobnie jak w pierwszy badaniu, samo opanowanie scenariusza zabawy nie spowodowało wzrostu ilości interakcji między dziećmi. Natomiast istotny wzrost nastąpił po wprowadzeniu podpowiedzi. Przy czym podpowiedzi nauczycielki ograniczały się tylko do: przydzielania ról na początku zabawy, zachęcania do pozostawania $\mathrm{w}$ podjętej roli oraz przypominania o konieczności wymienienia się rolami przed powtórzeniem zabawy. Częstość społeczno-komunikacyjnych interakcji, zgodnych z tematem zabawy, obniżyła się, kiedy nauczycielka przestała udzielać podpowiedzi, ale nadal była istotnie wyższa niż na początku badania.

Przedstawione wyżej dwa badania przeprowadzone przez zespół Howarda Goldsteina udowodniły, że łączne użycie scenariuszy zabaw tematycznych i podpowiedzi nauczycielek zaowocowało znacznym wzrostem ilości społecznych i komunikacyjnych interakcji między dziećmi w wieku przedszkolnym. Udowodniły również, że procedura może być $\mathrm{z}$ powodzeniem stosowana $\mathrm{w}$ integracyjnych grupach przedszkolnych, ponieważ przynosi korzyści zarówno dzieciom z różnego typu niepełnosprawnościami, jak i dzieciom pełnosprawnym.

W kolejnych badaniach Howard Goldstein oraz Connie Cisar analizowali skuteczność rówieśniczego tutoringu z jednoczesnym wykorzystaniem scenariuszy trzech zabaw tematycznych: w sklep zoologiczny, zabawę karnawałową oraz występ iluzjonisty25. Każdy

24 Ibidem.

${ }^{25}$ H. Goldstein, C.L. Cisar, Promoting interaction during sociodramatic play: Teaching scripts to typical preschoolers and classmates with disabilities, "Journal of Applied Behavior Analysis" 1992, nr 25, s. 265-280. 
scenariusz zawierał opisy czynności werbalnych i niewerbalnych charakterystycznych dla trzech ról. Np. w zabawie w sklep ze zwierzętami były to role: klienta, opiekuna zwierząt oraz sprzedawcy. Do każdej roli przypisano 10 wypowiedzi o zróżnicowanym stopniu złożoności: od rozbudowanych (np. „Chciałbym kupić domowego pieska, małego i figlarnego”, poprzez krótkie (np. „Pies”) do niewerbalnych (np. wskazywanie palcem figurki psa). W badaniu uczestniczyły trzy triady dzieci przedszkolnych, z których każda składała się z jednego dziecka autystycznego oraz dwóch dzieci pełnosprawnych. Dzieci uczyły się scenariuszy po kolei i po opanowaniu każdego podejmowały zabawy. Zadbano, aby rodzaj i częstość podpowiedzi nauczycielek była stała przez całe badanie. Opanowanie scenariuszy zabaw nie poprawiło jakości społecznokomunikacyjnych interakcji między badanymi dziećmi, co potwierdziły analizy przebiegu pierwszych zabaw. Natomiast zastosowanie podpowiedzi nauczycielek spowodowało znaczącą poprawę interakcji między dziećmi sprawnymi i niepełnosprawnymi. Ponadto każdy kolejny scenariusz był opanowywany przez badane dzieci szybciej i skutkował większym postępem w ilości i jakości interakcji. Sprawdzano też efekt generalizacji, czyli przeniesienie nabytych umiejętności $\mathrm{w}$ relacje $\mathrm{z}$ nowymi partnerami $\mathrm{W}$ tym celu modyfikowano skład triad. Pozostawiano dziecko z autyzmem, a jedno z dzieci pełnosprawnych wymieniano na pełnosprawnego rówieśnika z innej triady. Takie „przegrupowywanie" składu triad skutkowało dalszym wzrostem liczby interakcji oraz liczby wypowiedzi formułowanych przez dzieci. Te pozytywne zmiany były zapewne konsekwencją efektu nowości. Ale istotniejsze było to, że w relacjach z nowymi partnerami dzieci miały możliwość zdobycia nowych doświadczeń.

Badania prowadzone przez zespół Howarda Goldsteina niewątpliwie poszerzyły wcześniejszą wiedzę na temat tutoringu w formie uczenia się z rówieśnikami. Po pierwsze dzięki starannemu kontrolowaniu podpowiedzi nauczycielek autorzy udowodnili, że opanowanie scenariuszy zabaw tematycznych przez dzieci sprawne i niepełnosprawne prowadzi do znacznej poprawy spo- 
łeczno-komunikacyjnych interakcji między nimi. Po drugie udowodniono, że scenariusze zabaw tematycznych można dostosować do potrzeb dzieci o bardzo różnym poziomie rozwoju kompetencji społecznych i komunikacyjnych: poczynając od dzieci niemówiących, poprzez dzieci o minimalnym poziomie opanowania mowy aż po dzieci o wysokiej sprawności w posługiwaniu się mową. Po trzecie udokumentowano, że użycie więcej niż jednego scenariusza zabawy tematycznej jest bardzo korzystne. Mianowicie kiedy badacze posłużyli się scenariuszami trzech zabaw, okazało się, że dzieci opanowywały każdy kolejny scenariusz z większa łatwością. Ten wynik jest szczególnie wartościowy z punktu widzenia utrzymywania się nabytych sprawności w repertuarze zachowań dzieci oraz generalizacji, czyli wykorzystywania nabytych umiejętności w nowych sytuacjach. Analiza przebiegu zabaw wykazała, że powtarzały się $\mathrm{w}$ nich elementy werbalne $\mathrm{z}$ różnych scenariuszy - np. podziękowania, pożegnania, płacenie i wydawanie reszty, pytanie partnerów czego sobie życzą itp. Zaobserwowany transfer słownictwa może wyjaśniać, dlaczego kolejne scenariusze były przyswajane szybciej, a kolejne zabawy obfitowały w liczniejsze interakcje i dłuższe wymiany wypowiedzi między badanymi dziećmi ${ }^{26}$.

Dotychczasowe badania nad tutoringiem $\mathrm{w}$ formie uczenia się $\mathrm{z}$ pełnosprawnymi rówieśnikami $\mathrm{w}$ trakcie zabaw tematycznych pozwalają na sformułowanie czterech wniosków. Po pierwsze największy postęp w umiejętnościach społeczno-komunikacyjnych, tak $\mathrm{u}$ dzieci niepełnosprawnych, jak i pełnosprawnych uzyskuje się dzięki zastosowaniu kilku scenariuszy zabaw tematycznych. Po drugie podpowiedzi nauczycieli w takcie trwania zabawy zapewniają jej sprawny przebieg i ułatwiają dzieciom nabywanie nowych umiejętności ${ }^{27}$. Po trzecie miarą skuteczności prowadzonych oddziaływań są nie tylko pozytywne zmiany obserwowane w zacho-

${ }^{26}$ H. Goldstein, N. Schneider, K. Thiemann, Peer-mediated social communication intervention..., s. 191.

27 T.L. Stanton-Chapman, Promoting positive peer interactions in the preschool classroom: The role and the responsibility of the teacher in supporting children's sociodramatic play, "Early Childhood Education Journal” 2015, nr 43, s. 99-107. 
waniach dzieci w trakcie prowadzonych oddziaływań. Równie istotne jest utrzymywanie się zmian po zakończeniu oddziaływań oraz wykorzystywanie nabytych umiejętności w nowych sytuacjach. Po czwarte konieczny jest taki dobór scenariuszy zabaw, aby nabywane dzięki nim umiejętności wyraźnie różniły się od umiejętności nabywanych w trakcie codziennych zajęć w przedszkolu ${ }^{28}$. Wtedy łatwiej będzie rozstrzygnąć, czy oczekiwane zmiany w zachowaniach dzieci rzeczywiście są spowodowane przeprowadzonymi oddziaływaniami.

Badania, które przynajmniej częściowo próbowały zmierzyć się w wymienionymi wyżej problemami, przeprowadziły Tina StantonChapman i Martha Snell. Autorki starały się ustalić, na ile skuteczna jest opracowana przez nie metoda usprawniania społecznokomunikacyjnych umiejętności u dzieci z niepełnosprawnościami ${ }^{29}$. W badaniach uczestniczyło dziesięcioro dzieci w wieku czterech oraz pięciu lat z zaburzeniami w rozwoju mowy i rozwoju społecznym. Dzieci zostały połączone w pary i pozostawały w nich przez całe badanie. Zajęcia $\mathrm{z}$ zastosowaniem rówieśniczego tutoringu trwały od 20 do 25 minut i odbywały się codziennie (pięć razy w tygodniu) przez 25 tygodni. Na początku każdych zajęć badacze zapoznawali dzieci ze scenariuszem jednej z pięciu zabaw tematycznych: 1) w sklep spożywczy, 2) w wizytę u lekarza, 3) w budowniczych domu, 4) w wizytę u weterynarza oraz 5) w salon fryzjerki. Każdy scenariusz zawierał: opis zabawy, wzory wypowiedzi przypisane do poszczególnych ról, specyficzne dla danej zabawy słownictwo oraz ilustracje obrazujące przebieg zabawy. Po zaznajomieniu ze scenariuszem proszono dzieci, aby podzieliły się rolami i podjęły zabawę. Głównym celem prowadzonych oddziaływań było kształtowanie $\mathrm{u}$ badanych dzieci czterech umiejętności

${ }^{28}$ K.R. Jamison, L.D. Forston, T.L. Stanton-Chapman, Encouraging social skill development through play in early childhood special education classrooms, "Young Exceptional Children" 2012, nr 2, s. 7-9.

29 T.L. Stanton-Chapman, M.E. Snell, Promoting turn-taking skills in preschool children with disabilities: The effects of peer-based social communicative intervention, "Early Childhood Research Quarterly" 2011, nr 26, s. 303-319. 
komunikacyjnych, których przejawy szczegółowo analizowano i oceniano:

1. Inicjowanie rozmowy. Analizowano, na ile wypowiedzi inicjujące były wyraźnie skierowane do partnera, zrozumiałe i wypowiadane $z$ odpowiedniej odległości.

2. Odpowiadanie na inicjujące wypowiedzi partnera. Brano pod uwage, czy odpowiedź nawiązuje do tematu zaproponowanego w wypowiedzi inicjującej, jest zaadresowana do partnera i zrozumiała.

3. Posługiwanie się imieniem partnera. Sprawdzano, jak często badane dzieci, przed sformułowaniem wypowiedzi inicjującej, wypowiadały imię partnera w celu pozyskania jego uwagi.

4. Przestrzeganie reguły naprzemiennego zabierania głosu. Analizowano, czy dzieci rozpoczynały wypowiedź dopiero po tym, jak partner zakończył swoją. Brano również pod uwagę: dopuszczanie partnera do głosu; formułowanie wypowiedzi po to, aby rozmowa mogła trwać; proszenie, aby partner wyjaśnił swoje niezrozumiałe wypowiedzi, wyjaśnianie partnerowi własnych niezrozumiałych wypowiedzi, dominowanie $\mathrm{w}$ rozmowie oraz przerywanie wypowiedzi partnera.

Rówieśniczy tutoring $\mathrm{z}$ wykorzystaniem scenariuszy pięciu zabaw tematycznych okazał się bardzo skuteczny w przypadku posługiwania się wypowiedziami inicjującymi. Po zakończeniu oddziaływań około $75 \%$ inicjujących wypowiedzi badanych dzieci było skutecznych, tzn. skłaniało partnerów do udzielenia odpowiedzi. Natomiast oddziaływania były mniej owocne w przypadku umiejętności prowadzenia rozmowy ${ }^{30}$. Stwierdzono bowiem, że oddziaływania były wysoce skuteczne tylko w odniesieniu do jednego dziecka, umiarkowanie skuteczne w przypadku trojga dzieci, nieznacznie skuteczne w przypadku dwojga dzieci oraz nieskuteczne w przypadku czworga dzieci. Mimo to, jest to wynik korzystny,

${ }^{30} \mathrm{Za}$ rozmowę badacze uznawali sekwencję co najmniej czterech wypowiedzi pochodzące kolejno od każdego z partnerów i posiadających wyraźnie określony temat. 
zważywszy, że nawet u prawidłowo rozwijających się dzieci, przed końcem wieku przedszkolnego, dialogowa kompetencja komunikacyjna nie jest jeszcze w pełni ukształtowana ${ }^{31}$.

Tina Stanton-Chapman i Martha Snell stwierdziły również, że po zakończeniu badań dzieci wykorzystywały nabyte umiejętności z innymi rówieśnikami zarówno na placu zabaw, jak i w trakcie zabaw dowolnych w przedszkolu. U dziewięciorga dzieci stwierdzono: istotny wzrost częstości inicjowania interakcji z rówieśnikami, znaczny wzrost częstości i jakości zabaw z rówieśnikami oraz wyraźny spadek częstości zabaw samotnych. Ponadto u większości badanych dzieci zaobserwowano wzrost częstości pozytywnych interakcji z rówieśnikami zarówno w grupie przedszkolnej, jak i na placu zabaw. Te ustalenia są szczególnie cenne, ponieważ w wielu badaniach wykorzystujących rówieśniczy tutoring w celu usprawnienia społeczno-komunikacyjnych umiejętności niepełnosprawnych dzieci w wieku przedszkolnym stwierdzono, co prawda, istotne postępy $\mathrm{w}$ trakcie oddziaływań, natomiast nie stwierdzono przeniesienia nabytych umiejętności do nowych sytuacji32.

\section{Zakończenie}

Włączenie pełnosprawnych rówieśników w proces edukacji dzieci niepełnosprawnych jest korzystne dla jednych i drugich. Dzieci pełnosprawne mogą lepiej poznać i zrozumieć niepełnosprawnych kolegów oraz rozwinąć akceptującą postawę wobec nich. Mają okazję przekonać się, że z niepełnosprawnymi rówieśnikami można się bawić i rozmawiać, że można się od nich wielu rzeczy nauczyć, że ich wewnętrzny świat jest bogaty i godny po-

${ }^{31}$ A. Twardowski, Kształcenie dialogowej kompetencji komunikacyjnej u uczniów niepetnosprawnych intelektualnie, Instytut Pedagogiczno-Artystyczny UAM, Kalisz 2002, s. 11-41.

32 C.B. Denning, T.L. Stanton-Chapman, Effects of social communication Intervention on interactive play for young children with disabilities, "Journal of Education and Human Development" 2014, nr 3, s. 131-132. 
znania. Ponadto uczenie kogoś sprzyja uporządkowaniu i pogłębieniu własnej wiedzy oraz nabyciu nowych umiejętności33.

Rówieśniczy tutoring jest korzystny również dla dzieci z niepełnosprawnościami. Zwiększa się ich zaangażowanie w życie grupy, wzrasta liczba kontaktów z kolegami oraz rozmów, w których z powodzeniem mogą uczestniczyć. Niepełnosprawne dzieci mają okazję przekonać się, że pełnosprawni rówieśnicy obdarzają ich uwagą, chcą się z nimi bawić i rozmawiać. Mają okazję doświadczyć, że potrafię skutecznie wpływać na swoich partnerów. Ponadto zwiększa się ich autonomia, ponieważ w relacjach z rówieśnikami muszą bardziej polegać na sobie i dążyć do wypracowywania wspólnych rozwiązań.

Należy zauważyć, że dotychczasowe badania nad rówieśniczymi interakcjami o charakterze nauczającym były prowadzone $\mathrm{w}$ ten sposób, że rola tutorów przypadała zawsze dzieciom pełnosprawnym. Być może badacze milcząco zakładali, że tylko prawidłowo rozwijające się dzieci mogą występować w tej roli. Są jednak badania, które dowodzą, że również dzieci z niepełnosprawnościami z powodzeniem mogą pełnić role tutorów, o ile są odpowiednio wspierane przez dorosłych ${ }^{34}$. Niewątpliwie problem, w jaki sposób dzieci niepełnosprawne mogą odgrywać rolę wspierających partnerów swych niepełnosprawnych kolegów wymaga dalszych badań.

\section{Bibliografia}

Cooper C.R., Development of collaborative problem-solving among preschool children, “Developmental Psychology" 1980, nr 5.

33 A. Twardowski, Rola petnosprawnych rówieśników w procesie wspomagania rozwoju dzieci z niepetnosprawnościami, [w:] Wspomaganie rozwoju i rehabilitacja dzieci z genetycznie uwarunkowanymi zespołami zaburzeń, red. A. Twardowski, Wydawnictwo Naukowe PTP, Poznań 2004, s. 92.

34 T.L. Stanton-Chapman, C.B. Denning, K.R. Jemison, Exploring the effects of a social communication intervention for improving requests and word diversity in preschoolers with disabilities, "Psychology in the Schools" 2008, nr 45, s. 644-664. 
Damond W., Phelps E., Strategies uses of peer learning in children's education, [w:] Peer relationships in child development, red. T.J. Berndt, G.W. Ladd, John Willey \& Sons, New York 1989.

Denning C.B., Stanton-Chapman T.L, Effects of social communication Intervention on interactive play for young children with disabilities, "Journal of Education and Human Development" 2014, nr 3.

English K. Shafer K., Goldstein H., Kaczmarek L., Teaching buddy skills to preschoolers, [w:] Mental retardation and intellectual disabilities. Teaching students using innovative and research-based strategies, red. L. Wehmeyer, M. Agran, American Association on Mental Retardation, Annapolis Junction 2005.

Foot H.C., Morgan M.J., Shute R.H., Children helping children, John Wiley\&Sons, New York 1990.

Goldstein H, Cisar C.L., Promoting interaction during sociodramatic play: Teaching scripts to typical preschoolers and classmates with disabilities, "Journal of Applied Behavior Analysis" 1992, nr 25.

Goldstein H., Ferrell D.R., Augmenting communicative interaction between handicapped and nonhandicapped preschool children, "Journal of Speech and Hearing Disorders" 1987, nr 52.

Goldstein H., English K., Shafer K., Kaczmarek L., Interaction among preschoolers with and without disabilities. Effects of across-the-day peer intervention, "Journal of Speech, Language and Hearing Research" 1997, nr 40.

Goldstein H., Schneider N., Thiemann K., Peer-mediated social communication intervention. When clinical expertise inform treatment development and evaluation, "Topics in Language Disorders" 2007, nr 2.

Goldstein H., Wickstrom S., Peer intervention effects on communicative intervention among handicapped and nonhandicapped preschoolers, "Journal of Applied Behavior Analysis" 1986, nr 19.

Goldstein H., Wickstrom S., Hoyson M., Jemieson B., Odom S., Effects of sociodramatic script training on social and communication interaction, "Education and Treatment of Children" 1988, nr 11.

Jamison K.R., Forston L.D., Stanton-Chapman T.L., Encouraging social skill development through play in early childhood special education classrooms, "Young Exceptional Children" 2012, nr 2.

Perret-Clermont A.N., Social interaction and cognitive development in children, Academic Press, London 1980.

Piaget J., Mowa i myślenie u dziecka, Książnica - Atlas, Warszawa - Lwów 1929.

Sainato D., Goldstein H., Strain P., Effects of self-evaluation on preschool children's use of social interaction strategies with their classmates with autism, "Journal of Applied Behavior Analysis" 1992, nr 25.

Stanton-Chapman T.L., Promoting positive peer interactions in the preschool classroom: The role and the responsibility of the teacher in supporting children's sociodramatic play, "Early Childhood Education Journal" 2015, nr 43. 
Stanton-Chapman T.L., Denning C.B., Jemison K.R., Exploring the effects of a social communication intervention for improving requests and word diversity in preschoolers with disabilities, "Psychology in the Schools" 2008, nr 45.

Stanton-Chapman T.L., Snell M.E., Promoting turn-taking skills in preschool children with disabilities: The effects of peer-based social communicative intervention, "Early Childhood Research Quarterly" 2011, nr 26.

Strain P.S., Effects of peer social initiations on withdrawn preschool children: Some training and generalization, "Journal of Abnormal Child Psychology" 1977, nr 5.

Strain P.S., Kerr M.M., Regland E.U., Effects of peer-mediated social initiation and prompting/reinforcement procedures on the social behavior of autistic children, "Journal of Autism and Developmental Disorders" 1979, nr 9.

Strain P.S., Shores R.E., Timm M.A., Effects of peer social initiation on the behavior of withdrawn preschool children, "Journal of Applied Behavior Analysis" 1977, nr 10.

Tudge J., Rogoff B., Wpływ rówieśników na rozwój poznawczy - podejście Piageta i Wygotskiego, [w:] Dziecko wśród rówieśników i dorostych, red. A. Brzezińska, G. Lutomski, B. Smykowski, Zysk i S-ka, Poznań 1995.

Twardowski A., Kształcenie dialogowej kompetencji komunikacyjnej u uczniów niepetnosprawnych intelektualnie, Instytut Pedagogiczno-Artystyczny UAM, Kalisz 2002.

Twardowski A., Rola petnosprawnych rówieśników w procesie wspomagania rozwoju dzieci z niepetnosprawnościami, [w:] Wspomaganie rozwoju i rehabilitacja dzieci z genetycznie uwarunkowanymi zespołami zaburzeń, red. A. Twardowski, Wydawnictwo Naukowe PTP, Poznań 2004.

Twardowski A., Wpływ nauczających relacji z petnosprawnymi rówieśnikami na rozwój dzieci z niepetnosprawnościami, [w:] Pedagogika specjalna - koncepcje i rzeczywistość. Socjopedagogiczne aspekty rehabilitacji osób niepetnosprawnych, red. T. Żółtkowska, M. Wlazło, ZAPOL, Szczecin 2008.

Twardowski A., Możliwości wykorzystania rówieśniczego tutoringu w edukacji dzieci $z$ niepetnosprawnością intelektualna, „Interdyscyplinarne Konteksty Pedagogiki Specjalnej" 2014, nr 5.

Wygotski L.S., Wybrane prace psychologiczne, PWN, Warszawa 1971. 